\title{
Adverse drug reaction suggested by a clinical vignette
}

\author{
This article was published in the following Dove Press journal: \\ Clinical Interventions in Aging \\ I I July 20I I \\ Number of times this article has been viewed
}

\section{Albert J Finestone \\ Temple University School of Medicine, Philadelphia, PA, USA}

I had a three-lobe pneumonia and toxic encephalopathy in 2004. A lumbar puncture did not show meningitis. Magnetic resonance imaging showed a macroadenoma of the pituitary gland. Prolactin level was significantly elevated, making the diagnosis a functioning prolactinoma requiring treatment. Initially, I was treated with the dopamine agonist cabergoline, which is also used in much larger doses to treat Parkinsonism. Recent reports have indicated heart valve damage in Parkinsonism patients treated with ergot-derived dopamine-receptor agonists. ${ }^{1,2}$

In his monumental book The Pituitary, Shlomo Melmed states that patients with this clinical problem who are taking cabergoline should be informed of the potential risk of heart valve damage and have a cardiac echo if they have an audible heart murmur. They can then continue their current medication or switch to bromocriptine, which has a lower risk. ${ }^{3}$

Norprolac (quinagolide), which can be obtained from England via Canada, is a well-tolerated alternative that controls the prolactin level and does not have the same risks as dopamine-receptor agonists.

I am a retired geriatrician, with considerable experience in restless legs syndrome. This syndrome is not uncommon in the elderly, although it is not noted in the index of Hazzard's Geriatric Medicine and Gerontology under this category nor under sleep disorders. ${ }^{4}$ The problem is treated with the dopamine agonists ripinirole and prampexole. Is it possible that lurking in this treatment is the potential for heart valve damage?

\section{References}

1. Zanettini R, Antonini A, Gatto G, Gentile R, Tesei S, Pezzoli G. Valvular heart disease and the use of dopamine agonists for Parkinson's disease. N Engl J Med. 2007;356(1):39-46.

2. Schade R, Andersohn F, Suissa S, Havercamp W, Garbe E. Dopamine agonists and the risk of cardiacvalve regurgitation. N Engl J Med. 2007;356(1):29-38.

3. Melmed S. The Pituitary. 3rd ed. Amsterdam: Elsevier; 2011.

4. Halter JB, Ouslander JG, Tinetti ME, Studenski S, High KP, Asthana S. Hazzard's Geriatric Medicine and Gerontology. 6th ed. New York: McGraw-Hill; 2009.

Fax +I 2157073675

Email afinesto@temple.edu

Clinical Interventions in Aging

\section{Publish your work in this journal}

Clinical Interventions in Aging is an international, peer-reviewed journal focusing on evidence-based reports on the value or lack thereof of treatments intended to prevent or delay the onset of maladaptive correlates of aging in human beings. This journal is indexed on PubMed Central, MedLine, the American Chemical Society's 'Chemical Abstracts Ser-

\section{Dovepress}

vice' (CAS), Scopus and the Elsevier Bibliographic databases. The manuscript management system is completely online and includes a very quick and fair peer-review system, which is all easy to use. Visit http://www.dovepress.com/testimonials.php to read real quotes from published authors. 